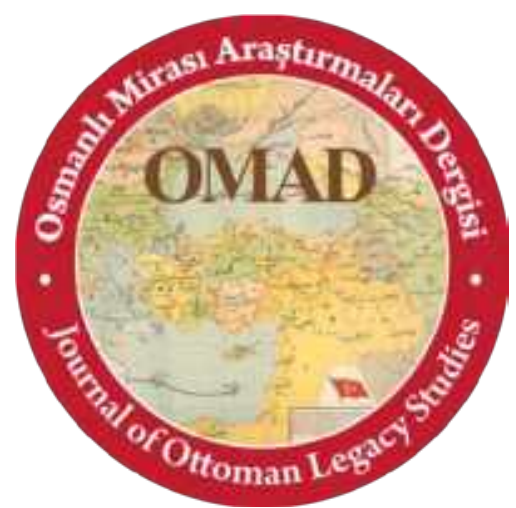

Osmanlı Mirası Araştırmaları Dergisi/Journal of Ottoman Legacy Studies

ISSN 2148-5704

www.osmanlimirasi.net

osmanlimirasi@gmail.com

Cilt 6, Sayı 14, Mart 2019 / Volume 6, Issue 14, March 2019

\title{
AVLONYA SANCAĞI VE YÖNETİMİ (1750-1800)
}

The Sanjak of Avlonia and Administrators (1750-1800)

Makale Türü/Article Types : Araştırma Makalesi/Research Article

Geliş Tarihi/Received Date : 18.01.2019

Kabul Tarihi/Accepted Date : 01.02.2019

Sayfa/Pages : 143-154

DOI Numaras1/DOI Number : http:/ /dx.doi.org/10.17822/omad.2019.116

\section{MEHMET İNBASI}

(Prof. Dr.), Erciyes Üniversitesi, Edebiyat Fakültesi, Tarih Bölümü, Kayseri / Türkiye, e-mail: minbasi@yahoo.com, ORCID: https:/ / orcid.org/0000-0002-3286-9902

\section{$\underline{\text { Atıf/Citation }}$}

İnbaşı, Mehmet, “Avlonya Sancağı ve Yönetimi (1750-1800)”, Osmanlı Mirası

Araştırmaları Dergisi, 6/14, 2019, s. 143-154.

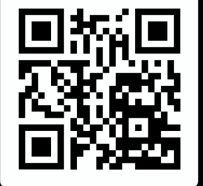

[- Scan me 

Osmanlı Mirası Araştırmaları Dergisi (OMAD), Cilt 6, Sayı 14, Mart 2019.

Journal of Ottoman Legacy Studies (JOLS), Volume 6, Issue 14, March 2019.

ISSN: $2148-5704$

\section{AVLONYA SANCAĞI VE YÖNETIMII (1750-1800) \\ The Sanjak of Avlonia and Administrators (1750-1800) \\ MEHMET İNBAŞI}

Öz: Güney Arnavutluk’ta önemli bir liman şehri olan Avlonya, büyük ve güvenli limanı ile tarih boyunca önemini koruyan bir şehir olup antik çağlardaki ismi Aulon'dur. Buraya Arnavutlar Vlorë, İtalyanlar Valona, Osmanlılar da Avlonya adını vermiş̧lerdir. Avlonya; önce Bizans ve Sırpların, 1378'den sonra İskenderiyeli Balşa beylerinin, 1417 'de ise Osmanlıların hâkimiyetine girdi ve burada bir sancak kuruldu. Avlonya, Osmanlıların Adriyatik sahillerindeki ilk limanı olması sebebiyle ayrı bir önem kazandı. Burada bir tersane kuruldu, ayrıca Osmanlı donanmasının Akdeniz'de mühim bir üssü hâline getirildi. Avlonya XVII. yüzyılda önemli ölçüde Müslüman nüfusa sahip oldu. Bunların çoğu mühtedi Arnavutlardı. 1690'daki geçici Venedik işgalinden sonra Avlonya ekonomik yönden gerilemeye başladı. XIX. yüzyılda Osmanlı Devleti'nin idari düzenlemeleri sonucu sancak merkezi olma özelliğini de kaybederek yeni teşkil edilen Yanya vilâyetinin bir kaza merkezi hâline geldi. Bu makalede XVIII. yüzyılın ikinci yarısında tahvil ve ruus kayıtları esas alınarak Avlonya'nın idari yapısı ortaya konulacak ve 1750 tarihinden başlanılarak 1800 tarihine kadar görev yapan idareciler ve bunların döneminde meydana gelen olaylar hakkında arşiv kaynakları esas alınarak bilgi verilecektir.

Anahtar Kelimeler: Avlonya, Arnavutluk, Adriyatik Denizi, Osmanlılar, 18. yüzyıl

Abstract: Avlonya, an important port city in southern Albania, is a city that has maintained its importance throughout history with its large and safe harbor and its name in ancient times is Aulon. The Albanians called it Vlorë, the Italians Valona and the Ottomans Avlonya. Avlonya, Byzantine and Serbs, after 1378 in Alexandria Balşa, the Ottomans in 1417 and entered into a sanjak dominated. Avlonya has gained a special importance since it was the first port of the Ottomans on the Adriatic coast. A shipyard was established here and it was also an important base of the Ottoman navy in the Mediterranean. Avlonya XVII. century, a significant Muslim population. Most of them were Albanians. After the temporary Venetian occupation of 1690, Avlonya began to decline economically. XIX. In the 19th century, after the administrative arrangements of the Ottoman Empire, it was the center of the sanjak. In this article XVIII. In the second half of the 19th century, the administrative structure of the Avlonia will be put forward on the basis of the bonds and ruus records.

Keywords: Vlorë, Albania, Adriatic Sea, Ottomans, $18^{\text {th }}$ Century

\section{Avlonya'nın Tarihçesi}

Güney Arnavutluk’ta önemli bir liman şehri olan Avlonya, Sasan adası ve Karaburun yarımadası ile çevrili bir körfezin kıyısında yer almaktadır. Büyük ve güvenli limanı ile tarih boyunca önemini koruyan şehrin Antikçağdaki ismi Aulon'dur. Buraya Arnavutlar Vlorë, İtalyanlar Valona, Osmanlılar ise Avlonya adını vermişlerdir.1

Eskiden beri önemli bir yerleşim merkezi olan şehir, sırasıyla Roma, Bizans ve Sırpların, 1378 'den sonra da İskenderiyeli Balşa beylerinin eline geçti. 1417'de Osmanlılar ülkenin iç kesimindeki Berat şehri ve Kanina Kalesi ile birlikte burayı hâkimiyetleri altına aldılar. Fatih Sultan Mehmed, Arnavutluk üzerinde kesin bir hâkimiyet tesis ettikten sonra birtakım idari düzenlemeler de gerçekleştirdi. Güney Arnavutluk'ta Sasan adası ve Karaburun yarımadası ile

\footnotetext{
${ }^{1}$ Machiel Kiel, “Avlonya”, DİA. 4, s. 118.
} 
çevrili olan körfez kesimindeki Avlonya, sancak yapıldı. ${ }^{2}$ Avlonya sancağı, Osmanlıların Adriyatik sahillerindeki ilk limanı olması sebebiyle ayrı bir önem kazandı. Burada bir tersane kuruldu, ayrıca Osmanlı donanmasının Akdeniz seferleri için önemli bir üs hâline getirildi. Kefalonya ve Ayamavra'nın fethinde önemli rol oynadı. 1480'de güney İtalya'ya sefere çıkan Gedik Ahmed Paşa hazırlıklarını burada yaptı. 1537'de Kanuni Sultan Süleyman Avlonya'da ikamet ile Korfu Seferi’ni buradan idare etti. ${ }^{3}$

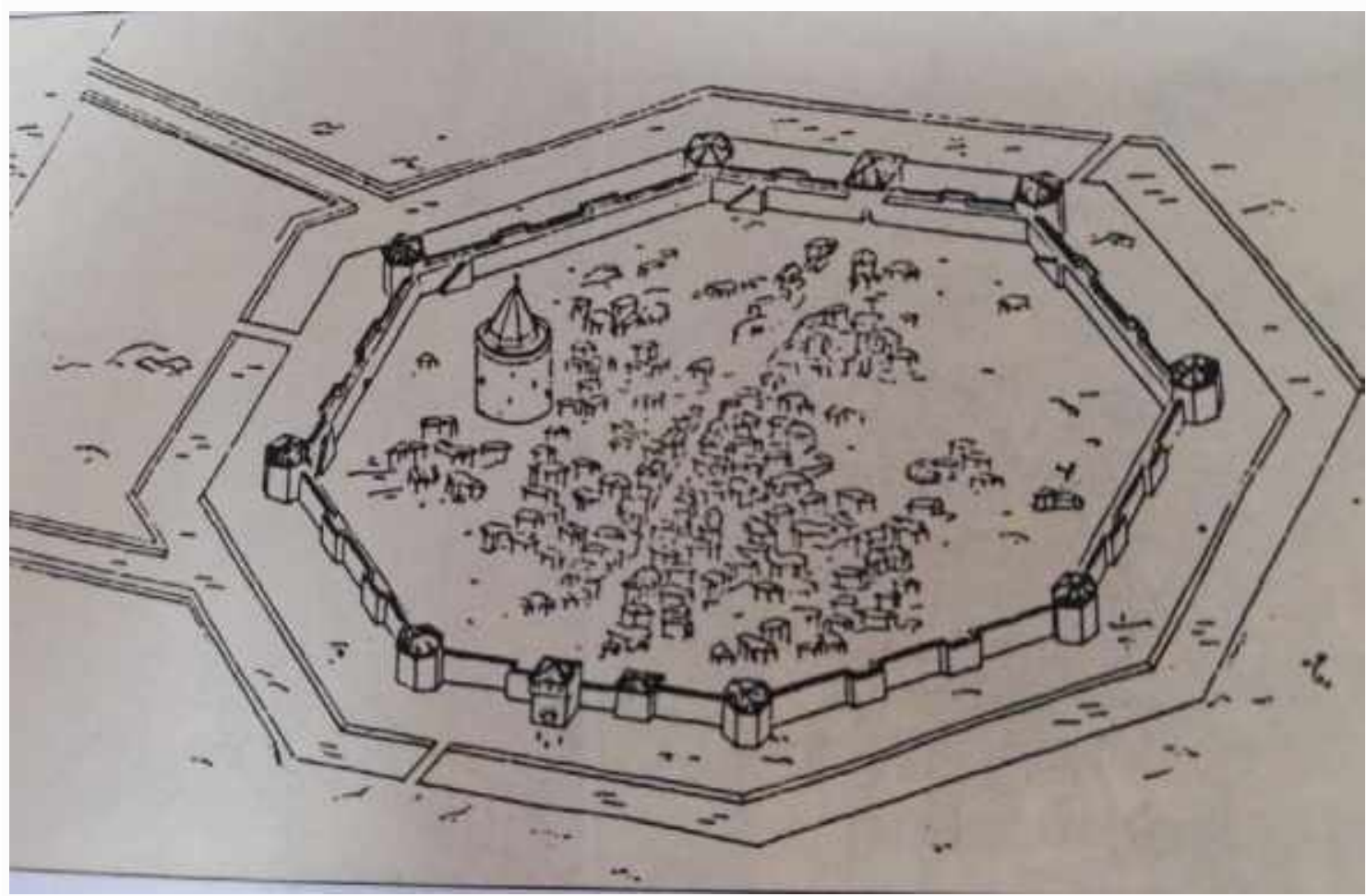

Resim 1: Kanuni Sultan Süleyman zamanında inşa edilen Avlonya Kalesi'nin XIX. yüzyılda Apollon Baçe’ye göre çizilmiş rekonstrüksiyonu (M. Kiel, Avlonya DİA. 4, s. 118)

XVI. yüzyıl başlarında Avlonya'da 665 Hristiyan, 97 Yahudi olmak üzere toplam 762 hane nüfus vardı. Ancak İnebahtı yenilgisinden sonra bazı Yahudi aileleri şehirden ayrıldı̆̆ı için Avlonya, ticari rolünü kaybetmeye başladı.4 XVI. yüzyılda Avlonya'da Müslüman nüfus mevcut değildi. Sadece Kanina Kalesi'nde bir Osmanlı askerî garnizonu ve bir cami vardı. Avlonya'daki kale Kanuni'nin emriyle 1542-43'te yapıldı. Kaleye büyük bir kule inşa edilerek toplar yerleștirildi. Avlonya ve Kanina kalelerindeki muhafizlar ciddi bir saldırıya karș1 koyabilecek sayıda olmadıklarından, bölgenin savunmasını Berat şehrindeki Müslümanlar üstlendi. Avlonya, 1638'de bir Venedik saldırısına uğradı ise de Venedik'in 30.000 duka altın tazminat vermeyi kabul etmesi ile savaşın önüne geçildi.5

Avlonya, XVII. yüzyılda çoğu mühtedi Arnavutlardan oluşan önemli bir Müslüman nüfusa sahipti. Özellikle de Arnavutların önemli bir kısmının Osmanlı Devleti’nin hizmetine

\footnotetext{
${ }^{2}$ M. Kiel, “Avlonya”, DIA. 4, s. 118; Bilgehan Pamuk, “XV. Yüzyılda Osmanlı Devleti - Arnavutluk İlişkileri”, Yeni Türkiye 66, Ankara 2015, s. 660.

${ }^{3}$ M. Kiel, “Avlonya”, DIA. 4, s. 118; B. Pamuk, "Osmanlı Devleti-Arnavutluk İlişkileri”, s. 660-661.

${ }^{4}$ M. Kiel, “Avlonya”, DIA. 4, s. 118; Avlonya'nın ticari önemi ve buradaki ticari faaliyetler hakkında geniş bilgi için bkz. Namık Sinan Turan, Seyahatnameden Yansıdığı Biçimiyle 17. Yüzyıl Arnavutluk Şehirlerinde Kimlik Kültür ve Toplumsal Yapılar”, Sosyoloji Konferanslart 51, 2015-1, (DOI: 10.18368/ IU/25910), s. 4, 11, 13,15.

${ }^{5}$ M. Kiel, “Avlonya”, DIA. 4, s. 118-119.
} 
alınması, İslamlaşma faaliyetini artırdı. XV ve XVI. yüzyıllarda bu durumu Osmanlı kayıtlarından görmek mümkündür.6 Evliya Çelebi'nin kaydına göre, Avlonya, bahçeler, bağlar, kestane, zeytin, incir, limon ağaçları ile çevrili birçok mahalleye bölünmüştü. Her birinde cami bulunan Hünkâr Camii, Mumcuzâde, Tabaklar, Hüseyin Ağa, Mahkeme, Çarşı mahalleleri vard1. Kanuni Sultan Süleyman Camii kubbeli ve üzeri kurşun kaplıydı. Şehirde bedesten yoktu.7 1690'daki geçici Venedik işgalinden sonra Avlonya, XVIII. yüzyılda gittikçe geriledi.8 1888-89 tarihli Yanya Vilâyeti Salnâmesi'ne göre Avlonya'da 490 ev ve 9 han vard1. Avlonya kazas1 ise 22.577 Müslüman, 3.316 Hristiyan-Ortodoks nüfusa sahipti. Bu rakamlar yerli nüfusun hemen hemen tamamıyla İslamlaştığını gösterir. Balkan Savaşı sırasında Arnavut milliyetçilerinin üssü olan Avlonya, I. Dünya Savaşı'na kadar Arnavutluk'un merkezi oldu. II. Dünya Savaşı'nda şehir geçici bir süre için tekrar yabancı işgaline uğradı ise de kısa süre içinde büyük bir gelişme gösterdi.9

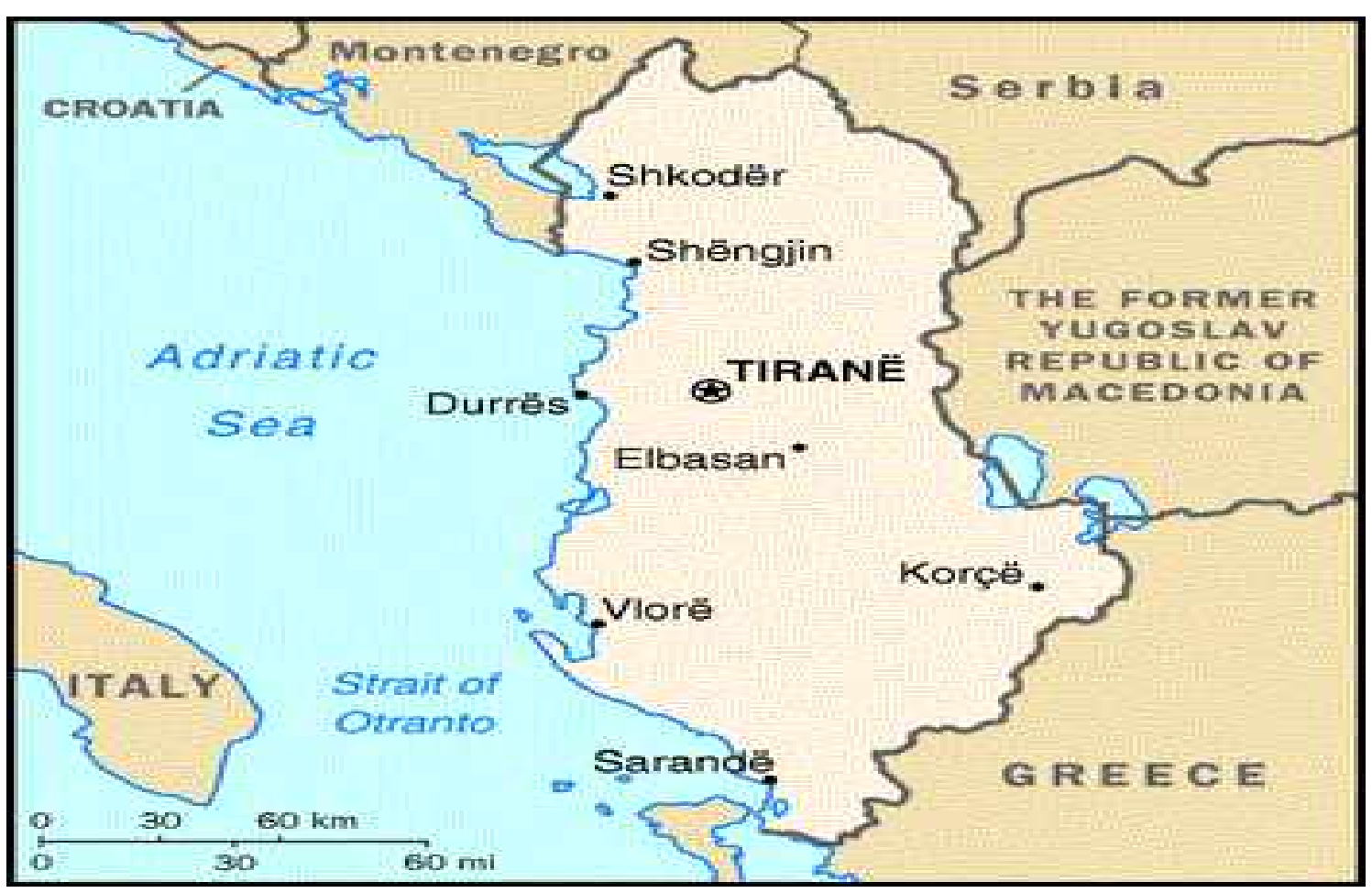

Harita 1: Arnavutluk Haritası

\section{2. İdari Yapı}

Avlonya Fatih zamanında bir sancak hâline getirilerek Rumeli eyaletine bağlandı. 14901491 tarihli Cizye defterine göre, Rumeli eyaletinde; Paşa, Gelibolu, Vize, Silistre, Niğbolu, Vidin, Sofya, Köstendil, Alacahisar, Vulçitrin, Prizrin, Bosna, Hersek, Semendire, İşkodra, Dukakin, Ohri, Elbasan, Avlonya, Yanya, Tirhala, Argiri Kasrı, Mora, Preveze, Midilli ve Kefe

\footnotetext{
${ }^{6}$ Ferit Duka, “XV-XVIII. Yüzyıllarda Arnavut Nüfusun İslamlaşması Süreci Üzerine Gözlemler”, OTAM. Sayı 2, Ankara 1991, s. 64-65.

${ }^{7}$ M. Kiel, “Avlonya”, DIA. 4, s. 119-120.

8 Eyüp Kul, “İskenderiye ve Avlonya Sancağı'nda Alınan Askeri Tedbirler (1705-1710)”, Sosyal ve Liberal Bilimlerde Yeni Yönelimler, C. III, Ed. H. Babacan, S. Özer, Ankara 2016, s. 897-908.

${ }^{9}$ M. Kiel, “Avlonya”, DIA. 4, s. 119-120.
} 
sancakları olmak üzere toplam 26 sancak vard1. ${ }^{10}$ Bunlardan Ergirikasrı sonradan kaza hâline dönüştürülüp Avlonya sancağına bağlandı.

XV. yüzyılın ikinci yarısından itibaren Rumeli Eyaleti, mirliva da denilen sancakbeyleri tarafından yönetilen ve daha küçük mülki, askerî ve idari bir ünite olan sancaklara ayrıldı. Paşa sancağı, XVI. yüzyıl başlarında sağ ve sol kol olmak üzere bir taksime tabi tutulmuştur. Balkanlar'daki fetihler genişledikçe, sancakların sayısı da arttı ve bu artışa paralel olarak XVI. yüzyılın ikinci yarısında yeni eyaletler kuruldu. ${ }^{11}$

1506'da Avlonya sancağına, Berat, Iskarapar, Kanina, Ergirikasrı, Delvine, Mazrak, Tepedelen ve Premedi kazaları bağlı idi. 1520'de Iskarapar ve Kanina kazaları başka bir sancağa bağlanırken bu defa Görince / Koriçe kazasının Avlonya'ya bağlandığı görülmektedir. ${ }^{12}$

1521-1522 tarihli vilayet ve sancak listelerinin kaydedildiği deftere göre, Rumeli eyaletinin, içerisinde Avlonya'nın da bulunduğu 33 sancağı vardı. ${ }^{13}$ Topkapı Sarayı Arşivi'nde bulunan ve 1526 tarihli olup beylerbeyleri ile sancakbeylerinin isimleri bulunan defterde, Rumeli eyaletine bağlı 31 sancağın ismi kaydedilmiştir ki bunlar arasında Avlonya da vardı. Bu tarihte Avlonya sancağı, sancakbeyi Süleyman Bey'in idaresinde olup yıllık 473.000 akçalık has tasarruf etmekteydi. ${ }^{14} 1527$ ve 1533 tarihli teşkilat defterlerinde de yine Rumeli eyaletinin sancakları arasında kayıtlıdır. ${ }^{15} 1537$ 'de Korfu seferi sırasında Kanuni'nin emriyle, Delvine merkezli olmak üzere Prekalme, Aydonat, Mazarak ve Kurveleş kazalarından oluşan Delvine sancağı kuruldu. ${ }^{16}$

1551-1553 tarihli Cizye defterine göre, Rumeli eyaletine tabi sancakların sayısı 26 tane olup bunlardan Avlonya, Delvine, İşkodra ve Elbasan Arnavutluk'ta idi. ${ }^{17}$ Rumeli'de 1541 'de Budin eyaletinin 1580 'de de Bosna eyaletinin kurulması ile XVI. yüzyılın ikinci yarısından itibaren Rumeli eyaletinin sancak sayısında azalma meydana geldi. Bu dönemde Rumeli eyaletinin 23 sancağı olup İlbasan, İskenderiye, Avlonya, Delvine ile birlikte yazılan Aydonat sancaklar1 Arnavutluk'tayd1. ${ }^{18}$

XVII. yüzyılda ise Rumeli eyaletinin sancak sayısında önemli bir değişikliğin olmadığı görülmektedir. Özellikle Osmanlı'nın Balkanlar'da, bu yüzyılda önemli fetih hareketlerine girişmediği, yeni ve büyük topraklar artık fethedilemediği için, eyaletin doğal sınırlarına ulaştığ 1 , ihtiyaç durumuna göre bazı yeni eyaletlerin kurulduğu kayıtlardan anlaşılmaktadır.

Osmanlı idaresinin teşkiliyle birlikte Avlonya, XVI. yüzyılın sonlarına kadar barış ve refah içerisindeydi. Ancak timar sisteminin bozulması ve mali sistemin zayıflaması diğer bölgeleri olduğu gibi Arnavutluk'u da etkiledi. Maliyenin zayıflaması, yeni vergiler ihdası ve cizyenin arttırılması, Hristiyan nüfusun itirazına sebep oldu. Arnavutluk tarafları başta olmak üzere Balkanlar'ın birçok yerinde vergi tahsilinde problemler yaşandı. Avlonya sancağında da vergi tahsilinde çekilen sıkıntılar, uzun süre devam etti. Nitekim bu çalışmada inceleme konusu olan Tahvil defterindeki kayitlarda da bölgeye tayin edilen idarecilerin vergileri eksiksiz olarak toplaması şartı getirildi.

\footnotetext{
${ }^{10}$ Skender Rizaj, Kosova Gjate Shekujve XV, XVI Dhe XVII Administrimi, ekonomia, Shogeria dhe Levizja popullare, Pristhine 1982, s. 42

${ }^{11}$ Aleksandar Stojanovski, La Division Administrative Territoriale De La Macédoine Sous L'empire Ottoman Jasqua La Fin Du XVII Siécle, Macédoine, Skopje 1989, s. 88-89; A. Stojanovski, "XVII. Yüzy1lın Sonuna Kadar Makedonya'nın Osmanlı Hâkimiyeti Devrinde İdari Taksimatı”, Çev. İ. Eren, Tarih Enstitüsü Dergisi. 4-5 (1974), s. 215.

${ }^{12}$ B. Pamuk, “Osmanlı Devleti - Arnavutluk İlişkileri”, s. 664-665.

${ }^{13}$ TSMA. D. 9772, vr. 1b-2b.

${ }^{14}$ TSMA. D. 10057 , vr. 1b-3a.

${ }^{15}$ TSMA. D. 5246 vr. 1b-3a; TSMA. D. 734, vr. 1b-9b.

${ }^{16}$ Mehmet İnbaş1, “Delvine Sancağı ve İdarecileri (1750-1800)”, Balkan Tarihi I, Ankara 2016, s. 148.

${ }^{17}$ Rizaj, Kosova Gjate Shekujve, s. 44.

${ }^{18}$ İ.Metin Kunt, Sancaktan Eyalete 1550-1650 Arasında Osmanlı Ümerası ve İl İdaresi, İstanbul 1978, s. 150-152.
} 
Tablo 1: XVII. Yüzyılda Rumeli Eyaleti

\begin{tabular}{|l|l|l|}
\hline Ayn Ali (1609) & Sofyalı Ali Çavuş ${ }^{20}$ & Telhisü'l-Beyan $^{21}$ \\
\hline Paşa (Sofya/ Manastır) & Paşa (Sofya) & Paşa (Sofya) \\
\hline Mora & Mora & Mora \\
\hline Üsküp & Üsküp & Üsküp \\
\hline Ohri & Ohri & Ohri \\
\hline İlbasan & İlbasan & İlbasan \\
\hline İskenderiye & İskenderiye-i Arnavud = İşkodra & İskenderiye \\
\hline Avlonya & Avlonya & Avlonya \\
\hline Delvine & Delvine & Delvine \\
\hline Yanya & Yanya & Yanya \\
\hline Tırhala & Tirhala & Tirhala \\
\hline Prizrin & Prizrin & Prizrin \\
\hline Vize & Vize & Vize \\
\hline Niğbolu & Niğbolu & Niğbolu \\
\hline Silistre & Silistre & Silistre \\
\hline Köstendil & Köstendil & Köstendil \\
\hline Çirmen & Çirmen & Çirmen \\
\hline Selânik & Selânik & Selânik \\
\hline Dukakin & Dukakin & Dukakin \\
\hline Kırkkilise & Kırkkilise & Kırkkilise \\
\hline Bender/Akkerman & Bender / Akkirman & - \\
\hline Alacahisar & Alacahisar & Alacahisar \\
\hline Vulçitrin maa Priştine & Vulçitrin & Vulçitrin \\
\hline Vidin & Vidin & Vidin \\
\hline Toplam: 23 & $\mathbf{2 3}$ & $\mathbf{2 2}$ \\
\hline
\end{tabular}

Görüldüğü üzere, XVII. yüzyılda Rumeli eyaleti idari yönden mevcut durumunu korumuştur. İki liste arasındaki fark ise İskenderiye sancağının İskenderiye-i Arnavud adı altında Işkodra olarak gösterilmesidir.

XVIII. yüzyılda ise; Rumeli eyaletinin sancak sayısında önemli bir azalmanın meydana geldiği görülmektedir. Bunun sebebi, özellikle 1683-1699 yılları arasında Osmanlı Devleti ile Kutsal İttifak arasında meydana gelen uzun savaşların, Osmanlı Devleti aleyhine sonuçlanması ve özellikle Balkanlar'da yaşanan toprak kayıpları ve Karlofça Antlaşması ile kaybedilen yerlerden ileri gelmektedir. XVIII. yüzyılda Rumeli eyaletinin sancak sayısı bir önceki yüzyıla göre önemli ölçüde azalarak 15'e düştü.

Tablo 2: Rumeli Eyaleti (XVIII. Yüzyıl)

\begin{tabular}{|l|l|l|}
\hline $\mathbf{1 7 0 0 - 1 7 1 8}^{22}$ & $\mathbf{1 7 1 7 - 1 7 3 0}^{23}$ & $\mathbf{1 7 5 0 - 1 8 0 0}^{24}$ \\
\hline Paşa Sancağı (Manastır) & Paşa Sancağ1 (Manastır) & Paşa Sancağı (Manastır) \\
\hline Köstendil & Köstendil & Köstendil \\
\hline Tırhala & Tirhala & Tırhala \\
\hline Yanya & Yanya & Yanya \\
\hline Delvine & Delvine & Delvine \\
\hline İlbasan & İlbasan & İlbasan \\
\hline İskenderiye & İskenderiye-i Arnavud = İşkodra & İskenderiye \\
\hline
\end{tabular}

\footnotetext{
${ }^{19}$ Ayn Ali Efendi, Kavanin-i Âl-i Osman Der Hülâsa-i Mezâmin-i Defter-i Divân, İstanbul 1280, s. 11-13.

${ }^{20}$ Sofyalı Ali Çavuş Kanunnâmesi, Haz. Midhat Sertoğlu, İstanbul 1992, s. 24-25.

${ }^{21}$ Hezarfen Hüseyin Efendi, Telhîsü’l-Beyân Fî Kavânîn-i Âl-i Osman, Haz. Sevim İlgürel, Ankara 1998, s. 116-118.

${ }^{22}$ Orhan Kılıç, Osmanlı Devleti'nin İdari Taksimatı, Eyalet ve Sancak Tevcihatı, Elazığ 1997, s. 45.

${ }^{23}$ Fehameddin Başar, Osmanlı Eyalet Tevcihatı (1717-1730), Ankara 1997, s. 17.

${ }^{24}$ BOA, A.DVN. Tahvil Defteri 16, s. 9-13.
} 


\begin{tabular}{|l|l|l|}
\hline Avlonya & Avlonya & Avlonya \\
\hline Ohri & Ohri & Ohri \\
\hline Alacahisar & Alacahisar & Alacahisar \\
\hline Selânik & Selânik & Selânik \\
\hline Dukakin & Dukakin & Dukakin \\
\hline Prizrin & Prizrin & Prizrin \\
\hline Üsküp & Üsküp & Üsküp \\
\hline Vulçitrin & & Semendire \\
\hline Toplam: 15 & $\mathbf{1 4}$ & $\mathbf{1 5}$ \\
\hline
\end{tabular}

Görüldüğü üzere Rumeli eyaletinin sancak sayısı yüzyılın ilk çeyreğinde 15 olarak kaydedilmiş iken Vulçitrin sancağının sancak listesinden çıkarılması ile 14'e düşmüş, incelenmekte olan tahvil defteri kayıtlarına göre de Semendire'nin ilave edilmesi ile yeniden 15 'e yükselmiştir. XVII. yüzyıl ile mukayese edildiğinde yaklaşık 7-8 sancak arasında bir azalma meydana gelmiştir. Ancak yine de sancak sayısı bakımından XVIII. yüzyılda Osmanlı eyaletleri arasında Rumeli eyaletinin hâlâ en büyük birkaç eyaletten birisi olduğu görülmektedir.

XIX. yüzyılda ise Rumeli eyaletine bağl1; Sofya, Manastır, Selânik, Üsküp, Köstendil, Ohri, Tırhala, Avlonya, Delvine, Vulçitrin, İskenderiye, Yanya, Dukakin, Prizrin ve Alacahisar sancakları olmak üzere toplam 15 sancak bulunmaktadır. ${ }^{25}$

\section{Avlonya Sancağı İdarecileri}

Avlonya sancağının idarecileri, bu makalenin inceleme konusu olan Başbakanlık Osmanlı Arşivi Divan-1 Hümâyun defterleri arasında bulunan ve vezir, beylerbeyi, sancakbeyi ve eyaletin defterdarları gibi yüksek dereceli devlet idarecilerinin isimlerinin kaydedildiği Tahvil defterlerindeki bilgilerden elde edilmiştir. 1755-1805 tarihleri arasında Osmanlı Devleti'nde eyalet ve sancaklar ile kaptan paşalığa tayinlerin yer aldığı bu defterdeki veriler, XVIII. yüzyılın ikinci yarısının aydınlatılmasında ve Osmanlı idari mekanizmasının anlaşılmasında çok önemli veriler içermektedir. Bu defter, "Der zemân-ı sadr-ı sudûrü'l-vüzerâ Mustafa Paşa ve Reisü'lküttâb Seyyid Mehmed Avni Efendi tâle bekâhümâ fi 8 L sene 1169" şeklinde bir başlıkla başlamaktadır. ${ }^{26}$ Avlonya sancağı ile ilgili defterde kaydedilen atamalar, 8 Şevval 1169 / 4 Temmuz 1756'dan itibaren başlamakta ve 3 Şevval 1206 / 24 Mayıs 1792 tarihine kadar 36 yıllık bir süreyi ihtiva etmektedir.

XVIII. yüzyılın hemen başlarında Avlonya sancağına tayin edilen idarecilerden Küçük Cafer Paşa-zâde Ali Paşa, 1718 yılında Avlonya'yı arpalık suretiyle tasarruf etmişti. ${ }^{27} 1725$ yılında Yanya sancağı ile beraber Avlonya sancağını da tasarruf eden Mahmud Paşa'ya yazılan hükümde bölgedeki eşkıya hareketinden bahsedilmişti. Mahmud Paşa hakkında pek çok olumsuz şeyler söylenmesi ve görevini ihmal etmesi üzerine yerine Ocak 1725 tarihinde Kurt Ömer Paşa tayin edilmiş ve bölgenin teftişi için de Bosna valisi Vezir Abdullah Paşa görevlendirilmişti. Yapılan tetkik neticesinde Mahmud Paşa'nın iftiraya uğradığı, Ömer Paşa'nın da eşkıyayı bastırmak, avarız ve cizye vergilerini tahsil etmek konusunda yetersiz kaldığı, Abdullah Paşa'nın tahriratıyla anlaşılmıştı. Mahmud Paşa'nın bölgede nüfuzlu bir kimse olması dolayısıyla yeniden Avlonya'ya tayin edilmesinin uygun olacağı bildirildiğinden Kasım 1725 'te yeniden Avlonya sancağının idaresine atanmıştı. ${ }^{28}$ Ancak bölgedeki eşkıya hareketinin sona erdirilemediği ve vergi tahsilinde problemin çözülemediği anlaşılmaktadır. Nitekim incelenen Tahvil defterinde de yine eşkıya hareketi ve vergi tahsilinde problemler yaşandığı ve bunların halledilmesi ile ilgili atama kayıtlarında bilgiler bulunmaktadır.

\footnotetext{
${ }^{25}$ Fazıla Akbal, “1831 Tarihinde Osmanlı İmparatorluğu'nda İdari Taksimat Ve Nüfus”, Belleten XV (1951), s. 619.

${ }^{26}$ BOA. A.DVN. Tahvil Defteri 16, s. 1

${ }^{27}$ O. Kilıç, Eyalet ve Sancak Tevcihatı, s. 92.

${ }^{28}$ F. Başar, Osmanlı Eyalet Tevcihatı, s. 42-43.
} 
İncelenen Tahvil defterine göre 1756-1792 tarihleri arasında 36 yıllık süre içerisinde 55 atama yapılmıştır. $\mathrm{Bu}$ atamalarda 26 vali görev yaparken beş kez ilhak, 24 defa da ipka yapılmak suretiyle valiler üç ila sekiz kez tekrar aynı göreve atanmışlardır.

En fazla ipka yapılan vali, Avlonya sancağına 1770 tarihinden kısa ara ile 1787 tarihine kadar üç defa atanan ve toplamda 17 yıl idarecilik yapan Kurt Ahmed Paşa idi. Kurt Ahmed Paşa, ilk tayini olan 1770-1774 yılları arasında dört defa ${ }^{29}$, 1774-1778 yılları arasında üç defa ${ }^{30}$ ve 1779-1787 yılları arasında ise sekiz defa ipka edilmek suretiyle ${ }^{31}$ toplam 17 yıllık idareciliği süresince 15 defa ipka edilmiştir. Bu durum Rumeli eyaletinde pek sık olarak görülen bir uygulama değildir. Ancak Arnavutluk'un özellikle de Avlonya'nın konumu, yaşanan eşkıyalık olayları ve vergi problemleri dolayısıyla böyle bir uygulamanın yapıldığı anlaşılmaktadır.

Kurt Ahmed Paşa'dan sonra en fazla ipka edilen Avlonya sancağı idarecisi ise onun damadı olan ve kayıtlarda Kurt Paşa damadı İbrahim Paşa olarak belirtilen kişi olup 1788 tarihinden 1792 tarihine kadar dört yıldan daha fazla idarecilik yapmış ve bu süre içinde altı defa ipka edilmiştir. ${ }^{32}$

Avlonya sancağının 1750-1800 yılları arasındaki idaresinde çok büyük bir etkisi ve rolü olan Kurt ailesinden pek çok kişinin idarecilik yaptığı görülmektedir. Bunlardan ilki EylülAralık 1764 tarihinde Avlonya sancağını idare eden Prizren sancağının eski mutasarrıfı Abdullah Bey, tahvil defterinde Kurt Mehmed Paşa-zâde Abdullah şeklinde kaydedilmiş ve Delvine sancağından bakiye kalan devlet malının tahsil ve teslimi ile görevlendirilmişti. ${ }^{33}$

Kurt ailesinin en önemli kişisi olan Ahmed Paşa'nın ise Avlonya sancağında bulunan devlete ait arazilerin ve mülklerin tanzim ve imar edilmesi, bölgenin eşkıyadan korunması, tahrire memur olan kimselerin görevlerini düzgün bir șekilde yapmalarına yardımcı olması, orduya göndermeyi taahhüt ettiği 2.000 süvariyi Nevruz'da göndermek şartlarıyla ${ }^{34}$ göreve getirildiği belirtilmekteydi. Aynı zamanda bu görevlerini hakkıyla yerine getirebilmesi için de 15 defa ipka edilmek suretiyle görevine devam etmesi imkânı verilmişti. Sonraki tayinlerde de hemen hemen aynı şartları yerine getirmesi kendisinde talep edilmişti. ${ }^{35}$

\footnotetext{
${ }^{29}$ Kurd Ahmed Paşa'nın ipkası sırasında şu açıklamalar yapılmıştır. "Min ba'ad me'mur olacağı hidmette mükemmel kapusu halkıyla mevcut bulunan şartıyla ipka kılınmıştır. Kema fi'l-evvel emlâk-İ hümâyunun tanzim ve tesviyesiyle imaret ve ol-havaliyi bi-kayd ve mazarrat-1 eşkıyadan hıfs u hırasete ve tahrir ve sevkine me'mur olduğu yılda ve süvariyi bir gün ikdam ordu-yı hümâyuna getürmeğe kemâl-i ihtimam ü dikkat ve sarf-1 sa'y u kudret eylemek şartıyla Paşa-yı mumâ ileyhe ibka". BOA. A.DVN. Tahvil Defteri 16, s. 9-13.

30 "Emlâk-i hümâyunun tanzim ve tesviyesiyle imarlarına ve ol-havali bi-kayd ve mazarrat-1 eşkıyadan hıfz u hırasete kemâl-i dikkat ve sarf-1 sa'y u kudret eylemek şartıyla..” şeklindeki kayıttan sonra aynı görevlerin devam ettirilmesi şartıyla 3 defa daha ipka edilmiştir. BOA. A.DVN. Tahvil Defteri 16, s. 9-13.

31 "Livâ-i mezbûr mutasarrıf-1 sabık1 Kurd Ahmed Paşa'ya şerefyâfte-i sudûr olan hatt-1 hümâyun-1 şevket-makrun mucibince diğer evâmir-i şerifte tafsil u beyan olduğu tarihte emlâk-i hümâyunu idare ve emvâl-i mîrinin tahsili ve vakt u zamanıyla tamamen eda ve teslimine ihtimam eylemek şatıyla derbentler başbuğluğu ile tevcih", şeklinde atama kaydından sonra "Livâ-i mezbûr Derbentler başbuğluğu ile paşa-yı mumâ ileyh Kurd Ahmed Paşa'ya bâ hatt-1 hümâyun kemakân ibka" şeklinde 8 defa daha ipka edilmiştir. BOA. A.DVN. Tahvil Defteri 16, s. 9-13.

32 "Avlonya sancağı sâbıka Yanya mutasarrıfı mir-mirandan Kurd Paşa damadı İbrahim Paşa dâmet ikbâluhûya" şeklindeki bir kayıttan sonra 6 defa ipka edildiği belirtilmektedir. BOA. A.DVN. Tahvil Defteri 16, s. 9-13.

33 "Livâ-i mezbûre Delvine Sancağının bekaya-yı mâl-ı mirîsini tahsil ve teslime ihtimam ve dikkat eylemek şatıyla ve Delvine sancağı ilhakıyla sâbıka Prizrin sancağına mutasarrıf Kurd Mehmed Paşa-zâde Abdullah dâme ikbâluhûya bâ hatt-1 hümâyun tevcih olunmuştur”, BOA. A.DVN. Tahvil Defteri 16, s. 9-13.

34 “Kema fi'l-evvel emlâk-1 hümâyunun tanzim ve tesviyesiyle imaret ve ol-havaliyi bi-kayd ve mazarrat-1 eşkıyadan hıfs u hırasete ve tahrir ve sevkine me'mur olduğu yılda ve süvariyi bir gün ikdam ordu-yı hümâyuna getürmeğe kemâl-i ihtimam ve dikkat ve sarf u sa'y ve kudret eylemek şartıyla”, BOA. A.DVN. Tahvil Defteri 16, s. 9-13.

35 "Emlâk-1 hümâyunun tanzim ve tesviyesiyle imarlarına ve ol-havali bi-kayd ve mazarrat-1 eşkıyadan hıfz u hırasete kemâl-i dikkat ve sarf u sa'y ve kudret eylemek şartıyla mutasarrıfı sabıkı Kurd Ahmed Paşa'ya tevcih”. BOA. A.DVN. Tahvil Defteri 16, s. 9-13.
} 
Tahvil defterinde Kurt Paşa-zâde Mehmed Bey şeklinde kaydedilen Ahmed Paşa'nın oğlu olan Mehmed Paşa ise Eylül 1787 'den Mart 1788'e kadar yaklaşık yedi ay görev yapmıştı. ${ }^{36}$ Kurt Ahmed Paşa'nın damadı olan İbrahim Paşa da dört yıldan daha fazla Avlonya sancağını idare etmiş ve altı kez de ipka edilmişti.

$\mathrm{Bu}$ idarecilerin önemli bir kısmının Avlonya'ya yakın sancaklardan atandığı kayıtlardan anlaş1lmaktadır. Bu sancaklar, İlbasan, Prizrin, Ohri, İskenderiye, Yanya, Dukakin ve Bosna sancakları Avlonya'ya yakın idari merkezlerdi. Bunların dışında yine Rumeli’de Vidin ve Niğbolu sancakları, adalardan Eğriboz muhafızı ile Hanya muhafızı Avlonya sancağında idarecilik yapmışlardı. Anadolu tarafından ise sadece Hüdavendigar ve Karahisar-1 Sahib sancaklarından Avlonya'ya idareci atanmıştı. Tayin edilen idarecilerin 12 tanesi vezir rütbesinde olup paşa unvanlı kimselerdi. Avlonya sancağına tayin edilen görevlilerin önemli bir kısmının sabıkâ mutasarrıf, sabıkâ mîr-mirân ya da bir kale veya adanın muhafızı rütbesinde olduğu defterdeki kayıtlardan anlaşılmaktadır. Bunların dışında mir-miran unvanlı dört kişi ile dergâh-1 âli kapıcıbaşı iken beylerbeylik payesi verilerek atanan bir kimse tespit edilmiştir. ${ }^{37}$

Avlonya sancağına atama yapılırken ${ }^{38}$ Avlonya ve Ilbasan sancaklarl ihsanıla; Liva-i mezbûr Avlonya sancağına ilhaken; Liva-i mezbûr Yanya sancă̆ıyla mean; eşkıyayı tedmir eylemek şartıyla zikr olunan Avlonya ve Delvine sancaklarl; Avlonya sancağı ve liva-i mezbur rütbe-i mir-miran ve Rum-ili beylerbeyliği payesiyle; mal-ı mirisini tamamen ve kâmilen tahsil ve zamaniyla hazine-i amireye eda ve teslime ihtimam ve dikkat eylemek şartiyla; Tirhala ve Ilbasan sancaklarının ilhakıyla şeklinde açıklamalar yapılarak Avlonya sancağının idaresi Delvine, İlbasan, Yanya ve Tırhala sancakları ile birleştirilerek tek bir mutasarrıfın uhdesine bırakılmıştır.

Tahvil defterinde ismine ilk rastlanılan görevli Kaplan Bey-zâde İbrahim Bey olup Temmuz 1756'dan Nisan 1757'ye kadar dokuz ay görev yapmıştır. İbrahim Bey'den sonra Avlonya sancağına tayin edilen Ömer Paşa'nın 1725'te görev yapan Ömer Paşa ile aynı kişi olup-olmadığı belgelerden anlaşılamamaktadır. Ömer Paşa iki buçuk ay görev yapmış ve bu sürede kendisinden eşkıyaya engel olması, üç senedir tahsil edilemeyen vergilerin tahsil edilmesi istenmişti. Bölgedeki sorunun giderilebilmesi için Rumeli valisi Ali Paşa'ya tahriratla sorulmuş, o da İskenderiye mutasarrıfi Ömer Paşa'yı tavsiye etmesi üzerine hem eşkıyayı bertaraf etmek hem de tahsil edilemeyen vergileri tahsil etmek şartıyla kendisine Avlonya'nın idaresi verilmişti. ${ }^{39}$

Ömer Paşa başarılı olamadığından kısa süre sonra aynı şartlarla Haziran 1757'de İskenderiye sancağının eski mutasarrıfı İsmail Paşa'ya aynı zamanda Delvine sancağı da ilhak edilerek Avlonya'nın idaresi verilmişti. İsmail Paşa dört buçuk ay görev yapmış ve yerine İskenderiye mutasarrıfı olan İslam Bey getirilmişti.

\footnotetext{
36 "Livâ-i mezbûr Kurd Paşa-zâde Mehmed beğe rütbe-i mir-miran ile bâ hatt-1 hümâyun tevcih", BOA. A.DVN. Tahvil Defteri 16, s. 9-13.

37 "Livâ-i mezbûr Delvine sancağı ilhakı ve rütbe-i mîr-miran ve Rum-ili beğlerbeğliği payesiyle dergâh-1 âli kapucubaşılarından olub hâlâ İsmail mütevellisi olan İsmail dâme mecduhû bâ hatt-1 hümâyun tevcih olunmuştur." BOA. A.DVN. Tahvil Defteri 16, s. 12-13.

${ }^{38}$ BOA. A.DVN. Tahvil Defteri 16, s. 12-13.

39 "Delvine sancağı ahalisi öteden berü haşûnet ve şekâvet üzere olduğuna binâen zimmetlerinde üç senelik emvâl-i mîrî bakayası olduğundan ma'âda geçen sene livâ-i mezbûrun eşkıyası Karlı-ili havâlilerine vâfir-i hisaret eyledikleri ecilden emvâl-i miriyenin tahsili ve eşkıya-yı mezbûrenin te'dibi içün kimilerin me'muriyeti münasibdir deyu Rum-ili valisi vezir Ali Paşa hazretlerine bundan mukaddemce keyfiyet istibkâ oldukda müşârun ileyhin tahrirâtı gelüb hülasâ-i mefhumundan sâbıka İskenderiye sancağı mutasarrıfı Ömer Paşa dâmet meâlihi müşârun ileyhin yanında bulunmağla mâl-i mîrînin tahsili eşkıyanın kuşmali şartıyla Avlonya sancağı paşa-yı mumâ ileyhe tevcih ve hidmet-i mezbûreyi eda edinceye dek İlbasan sancağı dahi ilhaken ihsân ve başbuğ nasb olunması ve hidmet-i mezbûreyi taahhüd ve hüccet-i şer'iyye vereceğini beyan etmekle livâ-i mezbûre bâ emr-i hümâyun tevcih olunmuştur.", BOA. A.DVN. Tahvil Defteri 16, s. 12.
} 
1759 tarihli tahvil kaydında eski Vidin ve Niğbolu sancaklarına mutasarrıf İsmail Paşa'ya tevcih edilirken Avlonya ve Delvine sancaklarında ortaya çıkan ve etrafa dehşet saçan eşkıyayı def etmek ve devletin bölgeden tahsil edeceği vergiyi salimen toplayıp bölgeye gerekli nizam ve intizamı vermek şartıyla tayin edilmişti. ${ }^{40}$ Sekiz ay bu görevi yürüten İsmail Paşa'nın eşkıya hareketine son verdiği anlaşılmaktadır. Çünkü bir sonraki tayinde eşkıya hareketinden bahsedilmemektedir.

Yaklaşı iki yıllık bir aradan sonra Eylül 1761'de İsmail Paşa'nın yeniden Avlonya ve Delvine sancaklarına idareci olarak tayin edildiği ve 1764 y1lına kadar üç yıl bu görevini sürdürdüğü anlaşılmaktadır. ${ }^{41}$ Tayin kaydında İsmail Paşa'nın görevinde başarısız olması sebebiyle vezirlik payesinin kaldırıldığı, ancak Veziriazam Ragıb Mehmed Paşa'nın tavassutu ile affedilerek vezirlik payesi üzerinde kalmak suretiyle yeniden Avlonya sancağına tayin edildiği ve dört defa da ipka edilerek taahhüt ettiği şartları yerine getirmesi istendiği belirtilmektedir.

1764 tarihinde Avlonya'nın idaresine getirilen Kurd Mehmed Paşa-zâde Abdullah üç buçuk aylık görevi süresince kendisinden bakaya kalan vergilerin tahsili istenmişti. ${ }^{42}$ Bundan sonra 1768 yılına kadar tayin edilen İsmail Bey, Mahmud Paşa-zâde Kahraman, Hacı Paşa-zâde Mehemmed ve Mahmud Beğ-zâde Süleyman gibi idareciler ${ }^{43}$ vergi ve asayiş meselesinin halledilmesi şartlarıyla Avlonya sancağına tayin edilmişlerdi.

May1s 1768'den Mart 1769'a kadar Avlonya idareciliğini yapan Cebresteli Hasan Paşa'dan yine bakaya kalan vergilerin tahsili ve eşkıyanın def edilmesi istenmişti. ${ }^{44}$ Mart 1769'dan Eylül 1770'e kadar bir buçuk yıl görev yapan Muhtar Paşa-zâde Mehmed Paşa'nın da benzer şartlarla görevde kaldığ

XVIII. yüzyılın ikinci yarısında Arnavutluk ve Avlonya'da büyük bir nüfuz sahibi olan Kurt ailesinin en önemli temsilcisi olan Kurt Ahmed Paşa, 1770'ten 1787 tarihine kadar kısa aralıklarla on yedi yıl idare etmiş̧ir ki, bu durum daha önce de belirtildiği üzere Rumeli Eyaleti sancaklarında pek rastlanan bir uygulama değildir.

Kurt Ahmed Paşa Eylül 1770 tarihinde Avlonya'ya tayin edilirken kendisinin Moton kalesi muhafızı olduğu belirtilmiş, akabinde mükemmel kapusu halkıyla ve Delvine sancağ ilhaken eskiden beri tahsil edilemeyen vergileri tahsil ve eşkıyayı bertaraf etmesi, 2.000 nefer süvariyi orduya göndermesi şartlarıyla bu göreve getirildiği bildirilmişti. ${ }^{45}$ Ahmed Paşa bu ilk tayininde dört defa ipka edilmişti. Üç aylık bir aradan sonra yeniden Avlonya sancağına tayin edilen Kurt Ahmed Paşa'nın bu ikinci görevi üç yıl sekiz ay sürmüş ve üç defa ipka yapılmıştı.

\footnotetext{
40 "Livâ-i mezbûrda ve Delvine sancaklarında zuhur eden eşkıyanın tedmir ve istîsalleriyle gereği gibi nizamını vermek ve livâ-i mezbûrînde olan atik ve cedid emvâl-i miriyyeyi tahsil ve ve istihkâ-yı tedmir eylemek şartıyla". BOA. A.DVN. Tahvil Defteri 16, s. 12.

${ }^{41}$ BOA. A.DVN. Tahvil Defteri 16, s. 12.

42 "Livâ-i mezbûre Delvine Sancağının bekaya-yı mâl-ı mirîsini tahsil ve teslime ihtimam ve dikkat eylemek şatıyla ve Delvine sancağı ilhakıyla sâbıka Prizrin sancağına mutasarrıf Kurd Mehmed Paşa-zâde Abdullah dâme ikbâluhûya bâ hatt-1 hümâyun tevcih olunmuştur”. BOA. A.DVN. Tahvil Defteri 16, s. 12.

43 "Livâ-i mezbûr Delvine sancağı ilhakı ba'zı şurût ile", BOA. A.DVN. Tahvil Defteri 16, s. 12.

44 “...emvâl-i mirinin tamamen tahsiline ve ol-havali bî-kayd ve mazarrat-1 eşkıyadan hıfs u hırasete kemâl-i dikkat ve sarf u s'ay ve kudret eylemek şartıyla", BOA. A.DVN. Tahvil Defteri 16, s. 12.

45 "Min ba'ad me'mur olacağı hidmette mükemmel kapusu halkıyla mevcut bulunan şartıyla", "Delvine sancağı dahi ilhaken tevcih", "Emlâk-i hümâyunun tanzim ve tesviye-i imarlarına ve ol havali bi-kayd ve mazarrat-1 eşkıyadan hıfz u hırasete ve tahririne me'mur olduğu iki bin nefer suvariyi bi-inâyet-i hak nevruzda ordu-yı hümâyuna tesyirlerinde kemâl-i dikkat ve sarf-1 sa'y u kudret eylemek şartıyla", "Kema fi'l-evvel emlâk-i hümâyunun tanzim ve tesviyesiyle imaret ve ol havaliyi bi-kayd ve mazarrat-1 eşkıyadan hıfz u hırasete ve tahrir ve sevkine me'mur olduğu yılda ve süvariyi bir gün ikdam ordu-yı hümâyuna getürmeğe kemâl-i ihtimam ü dikkat ve sarf-1 sa'y u kudret eylemek şartıyla”, BOA. A.DVN. Tahvil Defteri 16, s. 12-13.
} 
Ali Paşa, yine önceki görevinde olduğu gibi ${ }^{46}$ vergi tahsili ve eşkıyanın zararının engellenmesi şartlarıyla tayin edilmişti.

Yaklaşık altı ay kadar Ali Paşa ve Yakovalı Mehmed Paşa Avlonya sancağına tayin edildikten ve onlardan da vergi ve eşkıya meselesini halletmeleri istendikten sonra Mart 1779'da Kurt Ahmed Paşa'ya üçüncü defa Avlonya'nın idaresi tahsis edilmişti.

Kurt Ahmed Paşa'nın üçüncü defa tayini Mart 1779'dan Eylül 1787 y1lına kadar dokuz buçuk yıl aralıksız devam etmiş ve sekiz defa da ipka edilmişti. Avlonya ile çoğu defa birlikte zikredilen Delvine sancağı da bu dönemde Aydonat Kazası ayanından Osman Kuka-zâde Mustafa Bey'e tahsis edilmiş ${ }^{47}$ ve Delvine'de toplanamayan mirî vergilerin tahsil ve hazineye teslimi istenmişti.

Kurt Ahmed Paşa'dan da bu son görevi sırasında ${ }^{48}$ yine bölgedeki hasların muhafaza edilmesi ile vergi tahsilinin zamanında yapılması hususu şart koşulmuştu. Ancak gerek Ahmed Paşa'nın gerekse ondan sonra görev yapan oğlu Mehmed Bey ve damadı İbrahim Paşa'nın tayin şartları arasında vergi dışında eşkıyadan bahsedilmemesi, Avlonya ve Delvine çevresinde bu problemin çözülmüş olduğu düşüncesini akla getirmektedir.

Kurt Ahmed Paşa'nın oğlu Mehmed Bey altı buçuk ay, damadı İbrahim Paşa ise dört yıldan daha fazla görev yapmıştır. Tahvil defterinde incelenen dönemde Avlonya sancağının son idarecisi olduğu görülmektedir.

Osmanl1-Rus harplerinin de etkili olduğu XVIII. yüzyılın sonlarında başta Avlonya olmak üzere Arnavutluk'taki pek çok sancakta karışıklığın devam ettiği bilinmektedir.

\section{Sonuç}

Sonuç olarak, erken dönemlerden itibaren Osmanlı hâkimiyeti altına alınan Avlonya ve çevresinin idari yapı olarak şekillenmesi, Fatih döneminde tamamlanmıştır. Bu dönemde sancak statüsü verilen Avlonya, bu durumunu XIX. yüzyıl ortalarına kadar sürdürmüştür. Bölgenin dağlık olması, Venedik müdahaleleri, asi Arnavutların Osmanlı hâkimiyetine karşı gelmesi, vergi tahsilinde önemli sıkıntılar yaşanmış olmasına rağmen Avlonya, XV. yüzyılın başlarından Osmanlı Devleti'nin Balkanlar'da gücünü kaybettiği XIX. yüzyıl ortalarına kadar Osmanlı toprağı olarak varlığını sürdürmüştür. Sadece Avlonya değil, Arnavutluk'un birçok yerinde Osmanlı döneminin Türk-İslam mimari üslubunun özelliklerini bu gün de görmek mümkündür.

\section{Kaynakça}

BOA, A.DVN. Tahvil Defteri 16.

TSMA. D. 9772.

TSMA. D. 10057.

TSMA. D. 5246.

TSMA. D. 734.

Akbal, Fazıla, “1831 Tarihinde Osmanlı İmparatorluğu'nda İdari Taksimat Ve Nüfus”, Belleten XV (1951).

\footnotetext{
46 "Emlâk-i hümâyunun tanzim ve tesviyesiyle imarlarına ve ol havali bi-kayd ve mazarrat-ı eşkıyadan hıfz u hırasete kemâl-i dikkat ve sarf-1 sa'y u kudret eylemek şartıyla mutasarrıfı sabıkı Kurd Ahmed Paşa'ya tevcih", BOA. A.DVN. Tahvil Defteri 16, s. 12-13.

47 "Delvine sancağı Osman Kuka-zade Mustafa Paşanın uhdesine kayd ve tamamen tahsil ve vaktiyle hazine-i amireye ve havalata eda eylemek şartıyla zikr olunan Delvine sancağı ber-vech-i arpalık...”, BOA. A.DVN. Tahvil Defteri 16, s. 9-12

48 “....diğer evâmir-i şerifte tafsil u beyan olduğu tarihte emlâk-1 hümâyunu idare ve emvâl-i mîrinin tahsili ve vakt u zamanıyla tamamen eda ve teslimine ihtimam eylemek şatıyla derbentler başbuğluğu ile”, BOA. A.DVN. Tahvil Defteri 16, s. 13.
} 
Ayn Ali Efendi, Kavanin-i Âl-i Osman Der Hülâsa-i Mezâmin-i Defter-i Divân, İstanbul 1280.

Başar, Fehameddin, Osmanlı Eyalet Tevcihatı (1717-1730), Ankara 1997.

Duka, Ferit, "XV-XVIII. Yüzyıllarda Arnavut Nüfusun İslamlaşması Süreci Üzerine Gözlemler”, OTAM, Sayı 2, Ankara 1991.

Hezarfen Hüseyin Efendi, Telhîsü'l-Beyân Fî Kavânîn-i Âl-i Osman, Haz. Sevim İlgürel, Ankara 1998.

İnbaşı, Mehmet, “Delvine Sancağı ve İdarecileri (1750-1800)”, Balkan Tarihi I, Ankara 2016.

Kılıç, Orhan, Osmanlı Devleti'nin İdari Taksimatı, Eyalet ve Sancak Tevcihatı, Elazı̆̆ 1997.

Kiel, Machiel, “Avlonya”, DİA, 4.

Kul, Eyüp, “İskenderiye ve Avlonya Sancăğ'nda Alınan Askeri Tedbirler (1705-1710)”, Sosyal ve Liberal Bilimlerde Yeni Yönelimler, C. III, ed. H. Babacan, S. Özer, Ankara 2016, s. 897-908.

Kunt, İ. Metin, Sancaktan Eyalete 1550-1650 Arasında Osmanlı Ümerası ve İl İdaresi, İstanbul 1978.

Pamuk, Bilgehan, "XV. Yüzyılda Osmanlı Devleti - Arnavutluk İlişkileri”, Yeni Türkiye 66, Ankara 2015.

Rizaj, Skender, Kosova Gjate Shekujve XV, XVI Dhe XVII Administrimi, ekonomia, Shogeria dhe Levizja popullare, Pristhine 1982.

Sofyalı Ali Çavuş Kanunnâmesi, Haz. Midhat Sertoğlu, İstanbul 1992.

Stojanovski, Aleksandar, La Division Administrative Territoriale De La Macédoine Sous L'empire Ottoman Jasqua La Fin Du XVII Siécle, Macédoine, Skopje 1989.

Stojanovski, A., "XVII. Yüzyılın Sonuna Kadar Makedonya'nın Osmanlı Hâkimiyeti Devrinde İdari Taksimatı", Çev. İ. Eren, Tarih Enstitüsü Dergisi, 4-5 (1974).

Turan, Namık Sinan, "Seyahatnameden Yansıdığg Biçimiyle 17. Yüzyıl Arnavutluk Şehirlerinde Kimlik, Kültür ve Toplumsal Yapılar", Sosyoloji Konferansları 51, 2015-1, (DOI: 10.18368/IU/25910) 
Ek 1: BOA. A.DVN. Tahvil Defteri 16, s. 12-13.

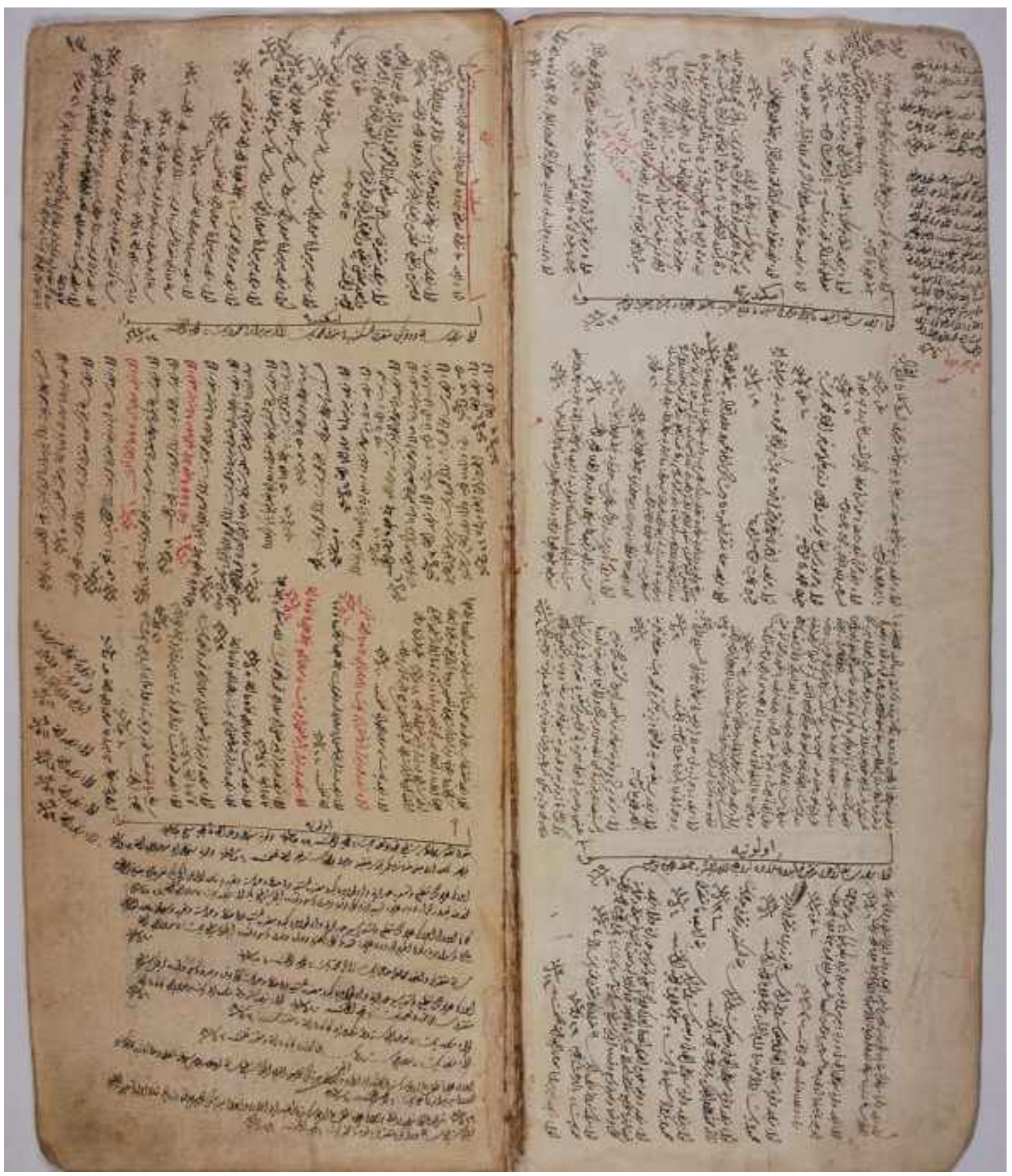

